\title{
Consumers' Perception of Quality and Health Beliefs of Sachet Drinking Water: Evidence from Obuasi in the Ashanti Region of Ghana
}

\author{
Benjamin Spears Ngmekpele, Cheabu (Corresponding author) \\ Faculty of Public Health \& Allied Sciences, Catholic University College of Ghana \\ P. O. Box 363, Fiapre - Sunyani
}

Tel: 233-322-394-376. E-mail: bscheabu@gmail.com

James Hawkins, Ephraim

Faculty of Public Health \& Allied Sciences, Catholic University College of Ghana

P. O. Box 363, Fiapre - Sunyani

Tel: 233-208-716-156. E-mail: egyamkow@gmail.com

Received: July 4, 2014 Accepted: August 7, 2014 Published: September 22, 2014

doi:10.5296/ijssr.v2i2.5916 URL: http://dx.doi.org/10.5296/ijssr.v2i2.5916

\begin{abstract}
The consistent rise in the utilization of sachet water as a primary source of drinking water for households and the general public has come of note in recent times. Government efforts to provide a safe and reliable source of drinking water has not been fully realized thus alternative sources of water provisioning are sought by the population. In spite of the varying levels of contamination reported in all studies in Ghana on sachet water quality, it still receives an appreciable level of trust from consumers. This study therefore employed both quantitative and qualitative research designs to elicit survey and semi - structured interview responses. The semi - structured interviews were a follow up to probe further respondents' health beliefs and concerns associated with sachet water. The study unveiled health beliefs associated with sachet water, concerns about tap and bottled water, respondents' admission to littering with plastic sachet, brand loyalty, attitudes towards the cross - checking of labeling requirements and respondents' perceived quality of sachet water. Others included respondents' consumption behavior and sachet water companies' compliance to labeling
\end{abstract}


requirements on sachet water. Many a respondent were unsure of any health beliefs with regard to sachet water but were concerned about its storage. Brand loyalty played a good role in consumers' choice of sachet water with organoleptic properties (colour, taste and odour) the main factors influencing the perceived quality of sachet water. Others included religious affiliation of sachet water producing companies, packaging and radio advertisements.

Keywords: Sachet water, health beliefs, consumers' perception

\section{Introduction}

In spite of the United Nations observation of World Water Day every March 22 of the year, with emphasis on sustainable management of fresh water resources, a relatively large proportion of the world's population still lacks safe drinking water. Since the hosting of the World Water Day in Ghana in 2005, many in Ghana came to realize the importance of water in individual lives and in national development. The government has also become more conscious in its duty to ensure that the World Health Organization's goal of providing good drinking water for all by 2025 will be realized in Ghana (Schiffer, 2006; Owusu, 2007). The problem therefore is that the Millennium Development Goal (MDG) targets for halving the population without a sustainable access to safe water remains a target yet to be achieved.

The United Nation Millennium Project (2005) reported that almost half of the people living in the developing world are suffering from one or more of the many diseases attributed to unsafe water and sanitation services. Even in parts of the developing world, where safe water resources are said to be available, it is interesting to note that the poor reliability of water supplies constitutes a major challenge. Hunter, Zmirou - Navier and Harteman (2009) provide evidence that the intermittent supply of water services often temporarily force people back to raw water which many a time is fraught with pathogens.

The efforts of metropolitan, municipal and district to providing safe and regular supply of treated water due to population growth has created room for the operation of other alternatives of vended water both for domestic and commercial purposes. The intermittent supply and low coverage of utility networks in many low income countries result in alternative means of water provisioning. Conan and Paniagua (2003) provide support to the aforementioned assertion that small-scale water providers will therefore grow steadily in areas where coverage and services are poor. The Kumasi metropolis, for example, has an estimated daily water requirement of at about $225,000 \mathrm{~m}^{3}$; but water supply from the Barekese and the Owabi dams provide less than 50 percent of that (CWSA, 2001). Consequently, entrepreneurial water vendors have filled the gap by selling water in water tanker vehicles, by "pay as you go" public tap services and by the emergence of sachet ${ }^{2}$ water. In sub - Saharan Africa, Bloom, Canning and Fink (2008) suggest that the increase in population can be attributed to industrialization - driven urbanization. It is surprising to learn that residents in Accra, the capital of Ghana, pay four times as much for water by volume than New Yorkers

\footnotetext{
1"Pay as you go" represents a public utility tap services where consumers are charged per bucket of water or specified container of water.

2 Sachet represents water filled and sealed in plastic bags by a machine.
} 
in America: slums residents pay up to eight times the public utility prices (UNDP, 2006) and up to twenty times in the dry season (Taylor et al., 2002).

In an interview with Obuasi residents aged 50 years and older, to understand the historical progression of vended drinking water, a common theme emanated. Water vending have existed since time immemorial, with Kjellen and McGranahan (2006) providing an extant review. For Kjellen and McGranahan (2006) water vending may be as old as human society but has been overshadowed by pipe infrastructure. According to interviewees, about a little over two decades ago, people hawked water in large aluminum vessels with iced blocks in them. These iced blocks were meant to keep the water cool. The thirsty public purchased this with cups provided by the vendor at about 5 Ghana pesewas. This went on for some time until the introduction of hand - filled and hand - tied sachet water, which according to them received a much patronage, as compared to the earlier practice. With the introduction of machine filled and sealed sachet water, the hand - filled and hand - tied sachet water witnessed low patronage and public trust. People branded the term as 'Panyin de panyin' ${ }^{3}$ to denote its seniority and superiority over the machine filled and sealed sachet water. Insanitary shortfalls contributed to the displacement of the hand - filled and hand -tied sachet. (Obiri Danso, Okere - Hanson, \& Jones, 2003).

Currently, machine - filled and sealed - sachet water have grown to become a primary source of drinking water. In Figure 1, evidence is provided in the ten regions in Ghana on the progression of tap and machine - filled and sealed - sachet water as primary sources of drinking water (Ghana Statistical Service, 2006). Ghana's ten administrative regions, show a neutral or slightly positive paths in the percentage of households using piped drinking water except for the Greater Accra, which decreased from 84.4 to 58.2 percent. The percentage of households primarily drinking from sachets grew to 34.5 in 2008, considerably higher than any of the other nine regions. The Greater Accra Region is reported to have fastest growing population in the country, growing at 4.4 percent annually between 1984 and 2000. The intermittency of water delivery may be attributable both to this growth and an inadequate water infrastructure investment (Gaisie \& Gyau-Boakye 2007).

Public acceptability of drinking water forms part of the World Health Organization's Guidelines for Drinking Water Quality (WHO, 2011). The guidelines incorporate consumer acceptability of taste, colour and odour among others. In developed countries, studies of drinking water safety perception have been particularly focused around bottled water consumption (Anadu, 2000; Doria, 2006). Similar studies have also focused on tap water (Grondin \& Dingrass, 1999; Doria, 1999; Pidgeon \& Hunter, 2009). The gap in literature on the perception on sachet water otherwise known as "pure water" is a point worthy of note. It is therefore the objective of this study to investigate consumers' perception and health beliefs associated with machine - filled and sealed - sachet water.

\footnotetext{
3،Panyin de pinyin" is an Asante (Twi) phrase which literally means the eldest is the eldest.

${ }^{4}$ Pure water is a popular term which refers to machine filled and sealed sachet water.
} 

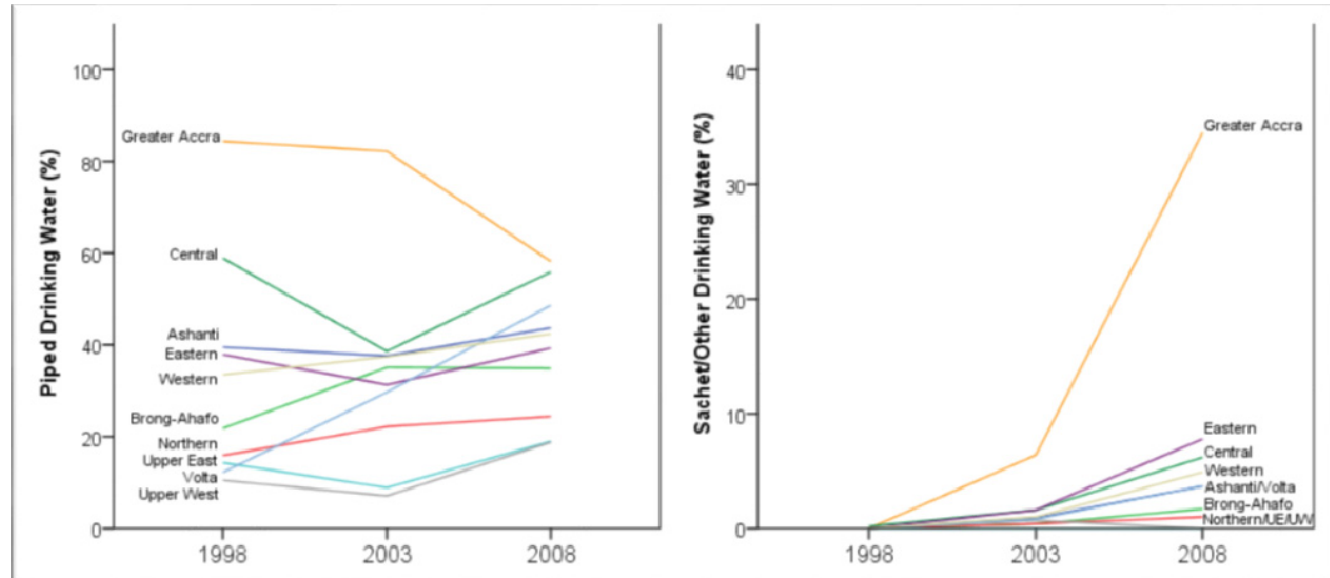

Figure 1. Percentages of households using piped drinking water vs. sachet/other water as the primary source of drinking water by Demographic Health Survey year for Ghana's ten administrative Regions

\section{Related Literature}

\subsection{Health Beliefs Associated With Water Quality}

There are a number of definitions on the concept of perception from the consumers' perspective. Among them are the following:

- "Perception is the process of selecting, organizing, and interpreting sensations into a meaningful whole" (Hanna \& Wozniak, 2013:75).

- "Perception is the entire process by which an individual becomes aware of the environment and interpret it so that it will fit into his or her frame of reference" Walters et al. (1989:333).

From the consumers' perspective, quality is seen broadly as excellence, high grade, superiority or non-inferiority. This can be termed as perceived quality as that is the consumers' judgment about the overall excellence or superiority of a product. Therefore, the literature on quality makes a distinction between perceived and actual quality (Garvin, 1983; Dodds \& Monroe, 1984; Jacoby \& Olson, 1985; Parasuramna et al., 1986; Zeithaml, 1988; Aakar, 1991). Whereas perceived quality depends (is based) on the judgment of the consumer, hence subjective; actual or objective quality describes the technical excellence or superiority of a product, thus termed as objective (Hjorth-Anderson, 1984; Monroe \& Krishman, 1985). However, some authors (Maynes, 1976) assert that all quality of some form are subjective, thereby making the claim that actual quality is non-existent.

The non - existing literature on consumer perception of quality and health beliefs on sachet water leaves much to be desired. Literature on sachet water has focused on microbial and physicochemical quality (Obiri - Danso et al., 2003; Dodoo et al., 2006; Ampofo et al., 2007; Addo et al., 2009; Ngozi, et al. 2010; Oyedeji, Olutiola, \& Moninuola, 2010), labeling 
requirements (Dada, 2009) and potential disease transmission (Kwakye - Nuako et al., 2007). The word sachet itself according to Stoler (2012) does not exist in the United Nations 440 page Human Development report focusing on global water crises (United Nations Development Programme, 2006). Even with the increasing levels of research to investigate the quality of sachet water in Ghana and countries neighboring it, a review of literature provides evidence that no study has attempted to investigate the consumers' perception of quality as well as health beliefs associated with sachet drinking water. Only Dada (2009) extended his study to investigate sachet water companies' compliance to proper labeling requirements.

Existing literature on water quality perception have centered on bottle (Ward et al., 2009) and tap water (Doria, 2006; American Water Works Association, 2005; Olson,1999) all of which are in the developed world. Doria (2006) confirms that many a research on water quality perception has been conducted in developed countries with stringent drinking water quality standards and reliable supplies, thus, extrapolations to developing countries may be inadequate.

This paper, therefore, sought to investigate the consumers' perception of sachet water quality, the health beliefs and other concerns associated with sachet water. Factors that contributed to the perception of quality included sachet water companies' adherence to proper labeling requirements and organoleptic properties. Health beliefs associated with sachet water with regard to other sources of drinking water (tap, borehole) and bottled water among the respondent population were also investigated.

\section{Methods}

\subsection{Study Area}

The Obuasi Municipality lies in the southern part of the Ashanti Region of Ghana between latitudes $5^{\circ} 35^{\prime} \mathrm{N}$ and $5^{\circ} 65^{\prime} \mathrm{N}$, and longitudes $6^{\circ} 35^{\prime} \mathrm{W}$ and $6^{\circ} 90^{\prime} \mathrm{W}$. It is the second largest political authority in the region after the Kumasi Metropolitan Assembly (K.M.A.) and covers a land area of about 162.4 square kilometers. It is bounded on the south by the Upper Denkyira District in the Central Region, east by the Adansi South District, west by the Amansie Central, and north by the Adansi North District. The municipal capital, Obuasi, is about $64 \mathrm{~km}$ drive from Kumasi, the regional capital. At the moment, there are 52 communities in the municipality with 30 Electoral Areas, and 1 urban council (Obuasi Municipal Assembly Medium Term Development Plan, 2006).

\subsection{Water Sources}

Generally, the Obuasi municipality has an undulating terrain with more of the hills rising above 500 meters above sea level. The municipality is drained by streams and rivers which include; the Pompo, the Kwabrafo, the Akapori, the Wheaseammo and the Kunka. All these water bodies are almost polluted by mining and other human activities. The Ghana Water and Sewage Corporation provides treated pipe water for the municipality. Estates owned by the AngloGold Ashanti are supplied treated water by the AngloGold Water Works Department. Areas in Obuasi which are not covered by any of the aforementioned treated water providers 
rely on wells, boreholes and streams.

\subsection{Settlement Pattern}

There are 52 communities which make up the municipality. $94 \%$ of the population in the municipality is concentrated along the major roads which run in the valleys. The composition and structure of household in the municipality presents a reflection of the household social structure of the Ghanaian society. There are five identified order of settlements. The first three order settlements include Boete, Obuasi Central and Mangoase. The two remaining order settlements are Wawase and Tutuka. A clear feature of the first to the fourth order settlements is that they are all along the major roads which also lie within a valley being flanked by high steep hills. It may be said that the location of settlements has been influenced by mining activities. Whereas some settlements have been relocated to pave way for gold extraction, others have been developed solely for the staff of the AngloGold Ashanti (AGA) and their families especially the Sam Jonah Estates, the Tiny Rowland Estates, and the Bruno Estates among others.

\subsection{Recruitment of Participants and Data Collection Methods}

All participants in this study were residents of Obuasi who provided passive consent to take part in the study. Recruitment and the administration of questionnaires and interviews were conducted from Monday to Friday in January through March 2013. Questionnaires were pre tested among seven respondents to allow for corrections and modifications.

After a briefing of participants on the objectives of the study, those who provided passive consent were provided with a validated self-administered questionnaire to answer at their own convenience. Research assistants returned a day later to collect the completed questionnaire. Participants who were unable to read or write were assisted by translating the questionnaire into the vernacular (Asante Twi ${ }^{5}$ ) in some instances Hausa ${ }^{6}$ and Dagaare ${ }^{7}$.In all, 303 respondents representing the first, second and third order of settlements in Obuasi completed and returned their questionnaire.

A follow - up interview was done among 25 respondents to probe further the health beliefs and concerns associated being investigated in the study. Every interview is an interpersonal drama with a developing plot (Pool 1957, cited in Holstein and Gubrium 1999, p.112) thus, a written set of flexible worded topics on concerns about tap and bottled water, health beliefs, environmental concerns and perceived quality of sachet water served as the conversation guide whiles allowing respondents to participate in their own style and expression.

\subsection{Data Analysis}

Quantitative data collected were entered and analyzed using the Statistical Package for Social Sciences (SPSS) version 21.0. Writing up qualitative research "converts private problems into

\footnotetext{
${ }^{5}$ Asanti Twi is a Ghanaian vernacular of the people of the Ashanti region.

${ }^{6}$ The Hausa constitutes the largest ethnic group in West Africa and predominantly Muslim. In Obuasi, they are concentrated at the center of the town known as "zongo".

${ }^{7}$ Dagaare is a Ghanaian vernacular of the people of the Upper West region.
} 
public issues, thereby making collective identity and solutions possible" (Richardson, 1990, p.28). Qualitative content analysis using elements of the grounded theory was used to analyze interview scripts. The grounded theory according to Strauss and Corbin (1990) is a qualitative research method that uses a set of procedures to develop an inductively derived grounded theory about a phenomenon. Data collection was directed by theoretical sampling where the sampling was based on theoretically relevant constructs which enabled the researcher to select respondents who maximized the potential to discover as many dimensions and conditions related to the phenomenon as possible (Strauss and Corbin, 1998) and in this case, a least researched phenomenon - consumers' perception of sachet water quality.

The inductive process of identifying themes was employed given the non - existence of research in the investigation of consumers' perception and health beliefs of sachet water.

\section{Summary of Issues of the Survey}

Results from the quantitative questionnaire included demographic data (age, sex, educational level and occupation of respondents), respondents' consumption behavior toward sachet water (reasons for preference for sachet water, sachet water brand loyalty, places of sachet water consumption), respondents' checking for labeling requirements, and problems consumers have encountered in relation to sachet water and their awareness of regulatory bodies.

\subsection{Demographic Information of Respondents}

In all, 303 respondents completed and returned their questionnaire. 153 representing 50.5 percent were males and 150 representing 49.5 percent were females. The age distribution showed respondents under 20 years to be 27 (8.9\%); respondents aged 20 - 29 were 76 (25.1\%); respondent aged 30 - 39 were 66 (21.8\%); respondents aged $40-49$ were 80 (26.4\%); respondents aged 50 - 59 were 38 (12.5\%); and respondents 60 years and above were 16 representing $5.3 \%$ of total respondents.

$54(17.8 \%)$ have had basic school education; 72 (23.8\%) had senior high school education; 85 (28.1\%) had university education; $71(23.4 \%)$ had education from other tertiary institutions apart from universities whilst $21(6.9 \%)$ have had no education at all.

The occupation distribution was categorized into the formal sector, informal sector and the unemployed. $113(37.3 \%)$ of respondents reported working in the formal sector; $100(33 \%)$ reported working in the formal sector whilst 90 (29.7\%) reported as unemployed. In this study, the formal sector referred to all jobs with regular hours and normal wages and are recognizes as income sources on which income taxes must be paid. The informal sector included all jobs which are not recognizes as normal income sources and on which taxes are not paid.

\subsection{Respondents Consumption Behavior of Sachet Water}

Respondents identified places where they normally drunk sachet water. At home, in public and both at home and in public were identified. 40 (13.2\%) reported drinking sachet water at home only thus do not purchase sachet water in public; 57 (18.8\%) reported drinking in 
public only thus drank either pipe or borehole water when at home; whilst 206 (68\%) reported drinking sachet water both at home and in public. The many respondents who drank sachet water both at home and in public further admitted that sachet water was their primary source of drinking water. This is evidenced in Figure 1 where sachet water is gradually replacing tap water as a primary source of drinking water.

Respondents revealed loyalty to certain brands of sachet water. 211 representing $69.6 \%$ reported having a specific brand of sachet water they purchase whilst 92 representing $30.4 \%$ reported having no specific brand at the point of purchase. It is common to find a group of people develop an affinity for particular brands of products and sachet water drinking was no different. It was revealed in this study that respondents' loyalty was in part a function of their affiliation to the producers. For example in Obuasi, the Catholic Church operates a sachet water company at its secretariat. Many a people ascribe quality and preference to the Catholic brand (S.Thomas).

On reasons for the purchase of sachet water, packaging, knowledge of the source of sachet water, availability, good taste, health benefits and concerns about tap and bottle water were identified as some reasons. Only $4(1.3 \%)$ attributed their preference to packaging; $58(19.1 \%)$ attributed it to knowing the source of the sachet water; $37(12.2 \%)$ attributed it to availability; $74(24.4 \%)$ attributed it to good taste; $84(27.7 \%)$ attributed it to health benefits whilst 46 $(15.2 \%)$ attributed their preference to concerns about tap and bottle water.

\subsection{Respondents Cross - Checking Labeling Requirements}

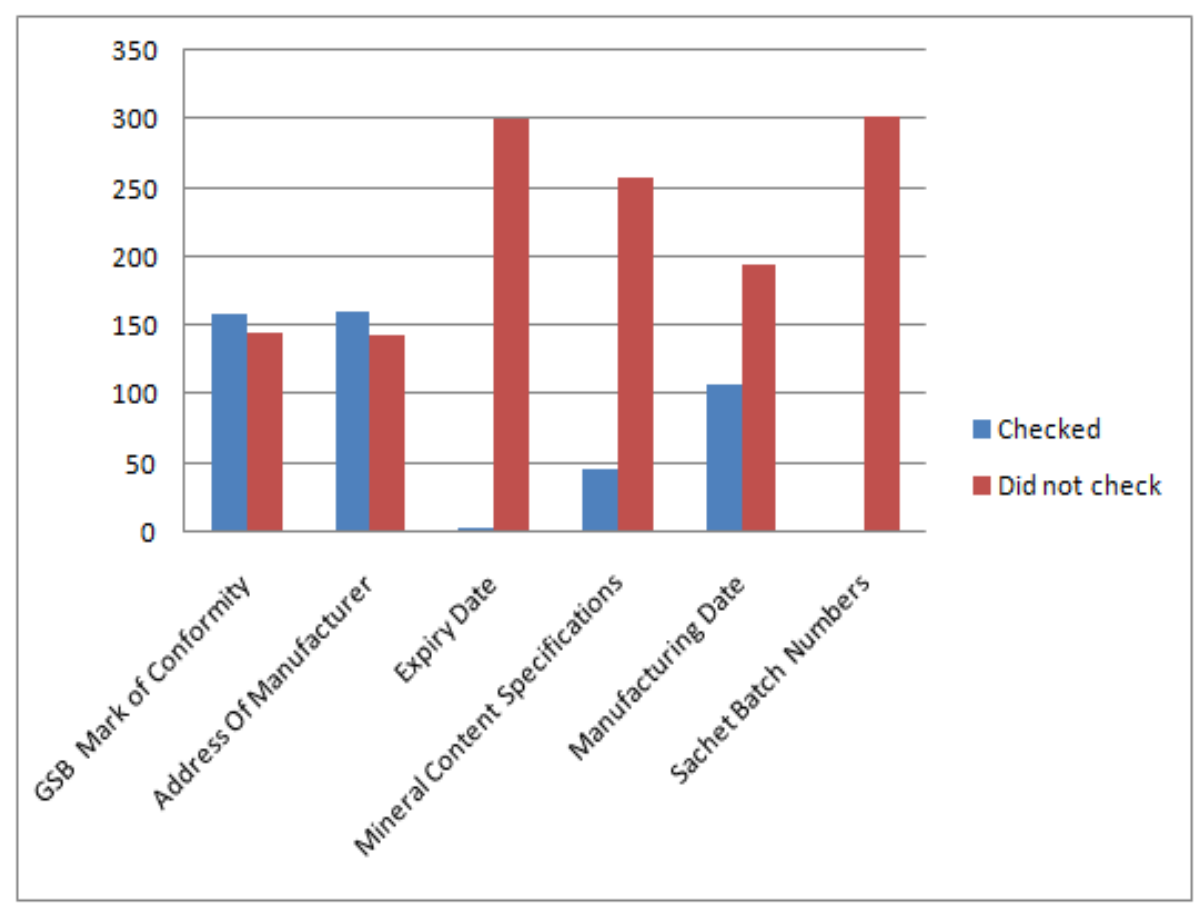

Figure 2. Respondents Cross - checking of Labeling Requirements 
Labeling requirements included the Ghana Standards Authority (GSA) mark of conformity, address of manufacturer, expiry date, mineral content specifications, manufacturing date and sachet batch numbers. 158 (52.1\%) reporting cross -checking the GSA mark of conformity, with 145(47.9\%) reported not checking; 160 (52.8\%) reported checking the address of the manufacturer whilst $143(47.2 \%)$ reported not checking. With regard to mineral content specifications only, 46 (15.2\%) checked whilst 257 (84.8\%) did not check. 108 (35.6\%) of respondents reported cross - checking manufacturing date while 195 (64.4\%) did not check. Only $3(0.99 \%)$ reported checking for expiry dates whilst $300(99.01 \%)$ reported not checking. Interestingly, all respondents reported not cross - checking batch numbers.

\subsection{Compliance to Labeling Requirements on Sachet Water by Sachet Water Companies}

Visual examination was undertaken to ascertain the compliance of sachet water products to the Ghana Standards Board's criteria for the labeling of products (Ghana Standard Board: 1998, 2004). Table 1 presents the outcome of the visual examination.

A field survey from December 2013 through February 2014 of 23 brands of sachet water produced and sold in Obuasi showed that none of the companies conformed to the required labeling requirements. In fact, all sachet water brands had only the GSB mark of conformity, net volume, name and address of manufacturer. It was also observed that the sachets had the inscription 'SEE SEAM' and 'THREE MONTHS AFTER PRODUCTION DATE' in place of expiry dates and manufacturing dates. Surprisingly, no dates were present on the seams of all sachet water products. These among others, confirm laxity in compliance of certain requirements meant to safeguard public health.

A vital observation was the absence of mineral content specifications and batch codes on sachet water products. The presence of accurate mineral content specifications of sachet water brands will be useful to inform consumers especially those on mineral restricted diets and those allergic to certain minerals. Batch codes will inform the manufacturer in the case of problem of quality with production day. In the case of sachet water in Obuasi however, mineral content specifications and batch codes were not in print on the sachets.

\section{Themes Emanating from Semi Structured Interview}

This part of the paper investigated respondents' concerns about sachet water consequently themes were generated from the qualitative data collected. Semi- structured interviews probed further what respondents concerns are about tap water and bottled water as against preference for sachet water; what they mean by health benefits and their perceptions of quality.

The themes were further categorized into concerns about tap and bottled water, health benefits about sachet water, environmental concerns associated with sachet products and labeling requirements. Selected quotes are presented to illustrate the themes among interviewees. 


\subsection{Concerns about Tap Water and Bottled Water}

Respondents expressed an array of concerns with respect to tap water as against bottled water. Municipal treated tap water many a time comes with varying odour, depending on the season of the year. This is usually accompanied with a change in color and taste: In the words of one respondent;

'Ah well...we don't even have a regular supply of tap water, and when the tap flows the water we see is frightening to bath not to talk of drinking'. (Female, Antobase central)

Another also said:

"If I show you tap water now, it will surprise you. For me and my family we don't trust it so we drink sachet water". (Male, Tutuka Aboagyekrom)

It is worthy of note that all interview respondents acknowledged bottled to be safest and purest. Concerns however, were centered on its quantity, cost and availability. Interestingly, some respondents did compare bottled water vis-à-vis sachet water:

"I don't know of any vended water purer than bottled water but it is very expensive. For just 10 pesewas I am able to have $500 \mathrm{ml}$ sachet water but will need GHC1.70 or more to purchase a 1.5 liters of bottled water, so see, it is expensive."(Male, Bruno Estates)

Even though respondent's comparison was centered on cost and quantity, availability of bottled water was a contributory factor. Concerns on availability rest on the fact that bottled water is rarely hawked as compared to sachet water.

\subsection{Health Beliefs about Sachet Water}

On health beliefs about sachet water, many drank sachet water due to its ubiquity and because the taps were not flowing, coupled with bad odour and color associated with tap water in Obuasi:

"...As for me and my family, we don't have any health benefits from sachet water. If it is not that the taps don't flow regularly, my family used to drink from the taps but these days when it flows the water comes with some bad smell and even the color is bad"( Female, Boete).

However, a few expressed concerns that sachet water was detrimental to health. Some concerns were about the exposure of sachet water to the mercy of the sun as the water ages in the metallic cages by vendors:

"I have an intrinsic feeling that as the water ages in these metallic cages their microbial Igerm content increases...the sachet, I mean the ink they use in printing, I fear it because we use our teeth to tear before we drink" (Female, Nyameso New Site).

"The other time I cut the sachet water, the inside of it was slippery, it has not happened once, many times" (Male, Akaporiso).

Another point of concern was that some respondents were unsure of the dangers associated with sachet when exposed and stays for long period of time. 
"The other time I heard on radio that the sachets can cause cancer if they are exposed to the sun and other unfavorable environmental conditions... for many of us it is a fear but we don't know what to do than to drink, at least we have no alternative." (Male, Kunka Junction)

With regard to sachet water having advantage over tap and borehole water in terms of health benefits, respondents were unsure.

\subsection{Admission to Contributing To Littering}

In spite of environmental concerns, many respondents admitted contributing to the problem by littering or throwing away indiscriminately the sachets any time they purchased sachet water.

Interviewer: "So, where how do you dispose of the sachet when you buy it in public?"

Respondent: "Ahhh, that one too... if am in a trotro ${ }^{8}$ I mostly throw it in the trotro but in a taxi the driver will be annoyed so I throw it outside (Female, Obuasi Trotro Station - Obuasi central market)

A conductor of a trotro expressed worry on how passengers litter in his vehicle:

"Come and see inside of my car, see the amount of waste you can count; sachets are the majority. For me as a mate I will sweep them and leave them here (the station), tomorrow Zoomlion ${ }^{10}$ will come and deal with it". (Male Conductor: Tutuka Trotro Station)

\subsection{Brand Loyalty and Cross - Checking Labeling Requirements}

Among the measures that seek to ensure sachet water quality, is sachet water producing company's adherence to labeling requirements. A good number of respondents were unsure if labels do matter even though the brand of water mattered in some instances. Brand loyalty was however upheld by most interviewees:

"When I call a sachet water seller and it is not S.Thomas ${ }^{11}$ or Pev ${ }^{12}$, forget about it. I won't buy. For these two brands I can at least trust them. These Roman Catholic waters are what I trust... as for the rest ...." (Market woman, Asonkore).

With regard to expiry dates, many were ignorant that sachet water has an expiry date:

"Am only interested in the name of the brand, does water too expire?" (Male, Kwabenakwa)

Mineral content specifications as a labeling requirement attracted interesting opinions and commentaries from respondents. They expressed worrying concerns of the required contents

\footnotetext{
8 Trotro is a commercial means of transport common in Ghana comprising mini buses with passenger capacity ranging $11-15$.

${ }^{9}$ Conductors are found in the trotro who collect fares from passengers and notifies the driver when a passenger wants to alight.

${ }^{10}$ Zoomlion is a waste management company Ghana who collect waste among other waste.

${ }^{11} \mathrm{~S}$. Thomas is a sachet water brand produced by the Catholic Secretariat in Obuasi.

${ }^{12} \mathrm{Pev}$ is another popular sachet water brand whose owner is also a Catholic but not for the Church in Obuasi.
} 
of the various minerals and even with those that may be harmful to human health yet may be present in sachet water. The question on mineral content specifications was limited to bottle water. A male respondent summarized:

"Mineral content specifications to be frank do not exist on sachet water ... I have only seen it on bottle water, it is even difficult to trust even the figures and minerals they claim constitute the water that they have printed on the surfaces ..." (Male, Sam Jonah Estates)

\subsection{Respondents on Sachet Water Quality}

Organoleptic properties, for example, water colour, taste and odour were the main issues that were mentioned as influencing the perceived quality of sachet among consumers. For respondents quality water meant water that is appealing in colour and taste and free from odour and unwanted particles. All 25 respondents reported water colour, taste and odour as properties of water that influences their perception. Other factors included the religious affiliation of sachet water producing companies, packaging and radio advertisements. Respondents who reported religious affiliation as a factor influencing their perception of quality mentioned the Catholic brands as trustworthy.

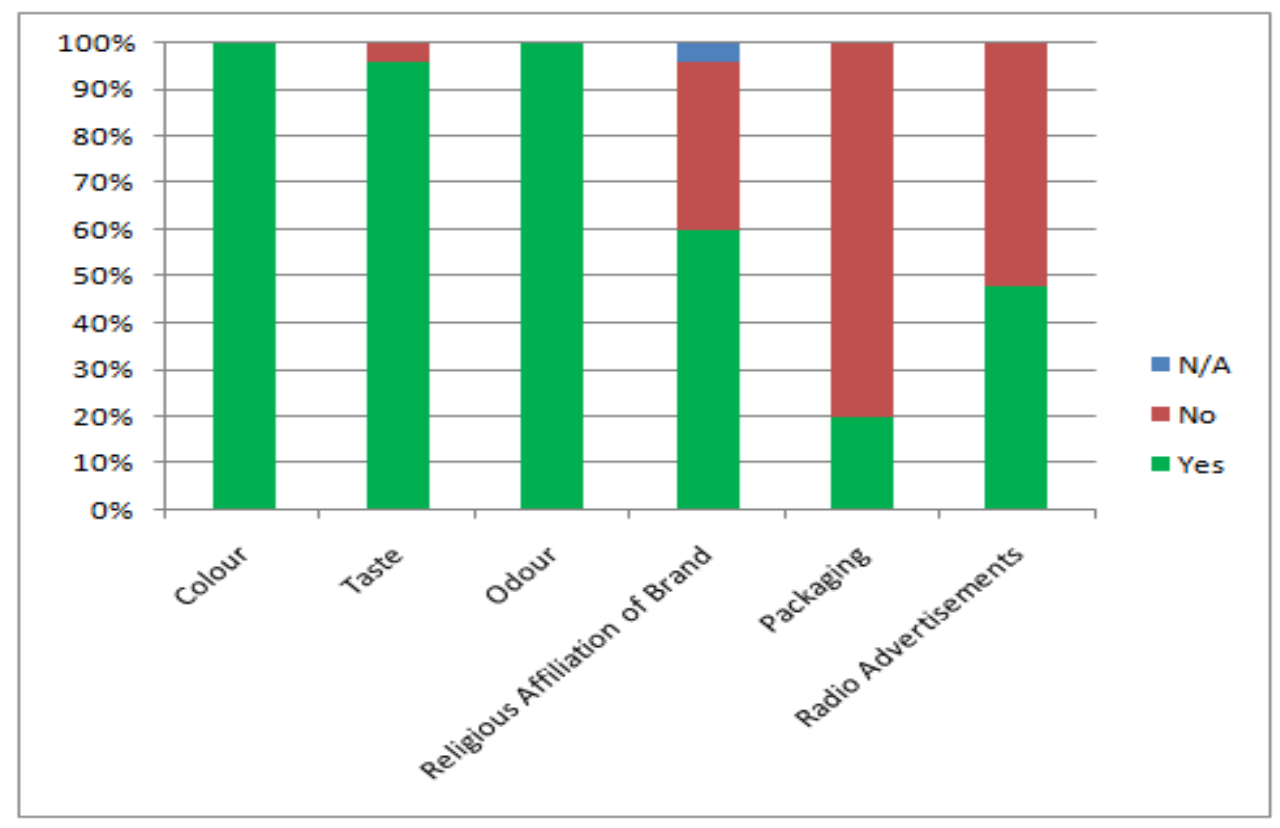

Figure 3. Factors Influencing Sachet Water Quality

Albeit the paucity of research with regard to the factors that may influence respondents perception of sachet water quality, it has been established in literature for bottled and other vended sources of water (Anadu, 2000; Doria, 2006; Grondin and Dingrass, 1999; Doria, 1999; Pidgeon and Hunter, 2009). 


\section{Conclusion and Recommendation}

A number of concerns emerged from the study with regard to sachet water. Consumers expressed a high level of trust for sachet water when compared with tap, borehole and hand filled and hand - tied sachet water. However trust of sachet water was low when compared with bottled water. Concerns raised in this study therefore centered on respondents perception of quality, consumption behavior of sachet water, cross - checking of labeling requirements, concerns about tap and bottled water, health beliefs with regard to sachet water and respondents admission to littering and last, brand loyalty.

The issues arising from this study afford the opportunity for further research. They include further research to determine how Faith - based sachet water producers influence respondents choice and perceived quality of a sachet water. This will provide substantial evidence on the role that Faith - based sachet water producers play in consumers' choice of sachet water brand.

Given the lack of research on sachet water quality from the consumers' point of view, we recommend that public education be initiated and intensified on labeling requirements especially and who to report to in the case of problems encountered as a result of sachet water.

\section{Acknowledgement}

The authors wish to thank the inhabitants of Obuasi who availed themselves to participate in the study. Special thanks also go to the field assistants who helped in the collection of data.

\section{References}

Aakar, D. A. (1991). Managing brand equity: Capitalizing on the value of a brand name. New York: Free Press. http://dx.doi.org/10.1057/bm.1993.9

Addo, K. K., Mensah, G. I., Bekoe, M., Bonsu, C., \& Akyeh, M. L. (2009). Bacteriological quality of sachet water produced and sold in Teshie-Nungua suburbs of Accra, Ghana. African Journal of Food Agriculture Nutrition and Development, 9, 1019-1030. http://dx.doi.org/10.4314/ajfand.v9i4.43874

Ampofo, J. A., Andoh, A., Tetteh, W., \& Bello, M. (2007). Microbiological quality and health risks of packaged water produced in Southern Ghana. Journal of Applied Science and Technology (JAST), 12, 88-97. http://dx.doi.org/10.4314/jast.v12i1.17477

Anadu, E. C., \& Harding, A. K. (2000). Risk perception and bottled water use. J Am Water Works Ass, 92, 82-92.

Dada, A. C. (2009). Sachet water phenomenon in Nigeria: Assessment of the potential health impacts. African Journal of Microbiology Research, 3, 15-21.

Bloom, D. E., Canning, D., \& Fink, G. (2008). Urbanization and the wealth of nations. Science, 319, 772-775. http://dx.doi.org/10.1126/science.1153057

Community Water and Sanitation Agency (CWSA). (2001a). Coverage data on potable water 
and sanitation facilities in rural communities and small towns in Ghana.

Dodoo, D. K., Quagraine, E. K., Okai-Sam, F., Kambo, D. J., \& Headley, J. V. (2006). Quality of "Sachet" waters in the Cape Coast municipality of Ghana. Journal of Environmental Science and Health Part A-Toxic/Hazardous Substances \&Environmental Engineering, 41, 329-342. http://dx.doi.org/10.1080/10934520500423238

Doria, M. F., Pidgeon, N., \& Hunter, P. R. (2009). Perception of drinking water quality and risk and its effect on behavior: A cross-national study. Science of the Total Environment, 407, 5455-5464. http://dx.doi.org/10.1016/j.scitotenv.2009.06.031

Doria, M. F. (2006). Bottled water versus tap water: understanding consumers' preferences. Journal of Water and Health, 4, 271-276.

Gaisie, S. K., \& Gyau-Boakye, P. G. (2007). Population growth, water/sanitation and health. In C. J. Mba\& S. O. Kwankye (Eds.), Population, health and development in Ghana: attaining the Millennium Development Goals (pp. 91-134). Accra: Sub-Saharan Publishers.

Ghana Statistical Service. (2006). Ghana Multiple Indicator Cluster Survey. Accra: Ghana Statistical Service.

Hanna, N., \& Wozniak, R. (2013). Consumer Behaviour: An Applied Approach. Dubuque: Kendall Hunt Publishing Company.

Holstein, J. A., \& Gubrium, J. F. (1999). Active interviewing. In A. Bryman \& R. G. Burges (Eds.), Qualitative research (vol. 2, pp. 105-21), Methods of Qualitative research. London: Sage..

Hunter, P. R., Zmirou-Navier, D., \& Hartemann, P. (2009). Estimating the impact on health of poor reliability of drinking water interventions in developing countries. Science of the Total Environment, 407, 2621-2624. http://dx.doi.org/10.1016/j.scitotenv.2009.01.018

Kjellén, M., \& McGranahan, G. (2006). Informal water vendors and the urban poor. In Human Settlements Discussion Paper Series, 26. London, UK: International Institute for Environment and Development.

Kwakye-Nuako, G., Borketey, P., Mensah-Attipoe, I., Asmah, R., \& Ayeh-Kumi, P. (2007). Sachet drinking water in Accra: the potential threats of transmission of enteric pathogenic protozoan organisms. Ghana Medical Journal, 41, 62-7. http://dx.doi.org/10.4314/gmj.v41i2.55303

Levallois, P., Grondin, J., \& Gingras, S. (1999). Evaluation of consumer attitudes on taste and tap water alternatives in Quebec. Water Science and Technology, 40(6), 135-9. http://dx.doi.org/10.1016/s0273-1223(99)00549-1

Mackey, E., Davis, J., Boulos, L., Brown, J., \& Crozes, G. (2005). Consumer Perceptions of Tap Water, Bottled Water, and Filtration Devices. London; IWA Publishing;

Ngozi, A. F., Romanus, I. I., Azubuike, A. C., Eze, A. T., Egwu, O. A., \& Collins, O. N. (2010). Presence of coliform producing extended spectrum beta lactamase in sachet-water 
manufactured and sold in Abakaliki, Ebonyi state, Nigeria. International Research Journal of Microbiology, 1, 32-36.

Obuasi Municipal Assembly Medium Term Development Plan (OMAMTDP). (2006). a draft Report. (Unpublished)

Obiri-Danso, K., Okore-Hanson, A., \& Jones, K. (2003). The microbiological quality of drinking water sold on the streets in Kumasi, Ghana. Letters in Applied Microbiology, 37, 334-339. http://dx.doi.org/10.1046/j.1472-765x.2003.01403.x

Oyedeji, O., Olutiola, P. O., \& Moninuola, M. A. (2010). Microbiological quality of packaged drinking water brands marketed in Ibadan metropolis and Ile-Ife city in South Western Nigeria. African Journal of Microbiology Research, 4, 96-102.

Mackey, E., Davis, J., Boulos, L., Brown, J., \& Crozes, G. (2005). Consumer Perceptions of Tap Water, Bottled Water, and Filtration Devices. London; IWA Publishing.

Olson, E. (1999). Bottled Water, Pure Drink or Pure Hype? [http://www.nrdc.org/water/drinking/bw/bwinx.asp]. New York: Natural Resources Defense Council (NRDC).

Richardson, L. (1990). Writing strategies: reaching diverse audiences. Newbury Park, CA: Sage.

Stoler, J. (2012). Spatial patterns of water insecurity in a developing city: Lessons from Accra, Ghana. San Diego State University and University of California, Santa Barbara. Unpublished Ph.D. thesis.

Strauss, A., \& Corbin, J. (1990). Basics of qualitative research: Grounded theory procedures and techniques (2nd ed.). Newbury Park, CA: Sage.

Taylor, P., Boussen, C. R., Awunyo-Akaba, J., \& Nelson, J. (2002). Ghana Urban Health Assessment, Activity Report 114. ed. U. Office of Health and Nutrition. Washington, DC: USAID.

United Nations Millennium Project. (2005). Health, Dignity, and Development: What Will it Take? ed. Task Force on Water and Sanitation. London, UK: Earthscan.

United Nations Development Programme. 2006. Human Development Report 2006: Beyond scarcity: Power, poverty and the global water crisis. New York, NY: United Nations.

Ward, A. L., Cain, L. O., Mullally, R. A., Holliday, S. K.,Werham, A. G. H., Baille, D. P., \& Greenfield, S. M. (2009). Health beliefs about bottled water: a qualitative study. BMC Public Health, 9, 196. http://dx.doi.org/10.1186/1471-2458-9-196

Walters, C. G., Bergiel, B. G., \& Sheth, J. N. (1989). Consumer Behaviour: A decision-marketing approach. Mason: South-Western Publishing Co.

WHO. (2011). Drinking water: Equity, safety and sustainability. Geneva: World Health Organization. 
WHO. (2011). Guidelines for Drinking-Water Quality (4th ed.). Geneva: World Health Organization.

Zeithaml, V. A. (1988). Consumer perceptions of price, quality, and value: a means-end model and synthesis of evidence. Journal of Marketing, 52(July), 2-22. http://dx.doi.org/10.2307/1251446

\section{Appendices}

Appendix 1. Physical Examination for Labeling Compliance of Sachet Water

\begin{tabular}{|c|c|c|c|c|c|c|c|}
\hline Sample Code & $\begin{array}{l}\text { GSB/FDB } \\
\text { Mark Of } \\
\text { Conformity }\end{array}$ & $\begin{array}{l}\text { Best } \\
\text { Before } \\
\text { Date }\end{array}$ & $\begin{array}{l}\text { Manufacturing } \\
\text { Date }\end{array}$ & $\begin{array}{l}\text { Mineral } \\
\text { Content } \\
\text { Specifications }\end{array}$ & $\begin{array}{l}\text { Batch } \\
\text { Code }\end{array}$ & $\begin{array}{l}\text { Net } \\
\text { Volume }\end{array}$ & $\begin{array}{l}\text { Name } \\
\text { Address Of } \\
\text { Manufactur } \\
\text { er }\end{array}$ \\
\hline OB/01 & $\sqrt{ }$ & $\times$ & $\times$ & $\times$ & $\times$ & $\sqrt{ }$ & $\sqrt{ }$ \\
\hline OB/02 & $\sqrt{ }$ & $\times$ & $\times$ & $\times$ & $\times$ & $\sqrt{ }$ & $\sqrt{ }$ \\
\hline OB/3 & $\sqrt{ }$ & $\times$ & $\times$ & $\times$ & $\times$ & $\sqrt{ }$ \\
\hline OB/4 & $\sqrt{ }$ & $\times$ & $\times$ & $\times$ & $\times$ & $\sqrt{ }$ & $\sqrt{ }$ \\
\hline OB/5 & $\sqrt{ }$ & $\times$ & $\times$ & $\times$ & $\times$ & $\sqrt{ }$ & $\sqrt{ }$ \\
\hline OB/6 & $\sqrt{ }$ & $\times$ & $\times$ & $\times$ & $\sqrt{ }$ & $\sqrt{ }$ \\
\hline OB/7 & $\sqrt{ }$ & $\times$ & $\times$ & $\times$ & $\sqrt{ }$ & $\sqrt{ }$ \\
\hline OB/8 & $\sqrt{ }$ & $\times$ & $\times$ & $\times$ & $\times$ & $\sqrt{ }$ & $\sqrt{ }$ \\
\hline OB/9 & & $\times$ & $\times$ & $\sqrt{ }$ & $\sqrt{ }$ \\
\hline OB/10 & & $\times$ & $\times$ & $\times$ & $\times$ & $\times$ & $\sqrt{ }$ \\
\hline
\end{tabular}

Key: Present $(\sqrt{ })$

Absent $(\times)$ 
Appendix 2. Summary of Survey Results $(n=303)$

\begin{tabular}{|l|c|c|}
\hline Demographic Information & Frequency & Percentage \\
\hline Male & 153 & 50.5 \\
\hline Females & 150 & 49.5 \\
\hline Highest Level of education & Frequency & Percentage \\
\hline Basic school & 54 & 17.8 \\
\hline Senior High school & 72 & 23.8 \\
\hline University education & 85 & 28.1 \\
\hline Other tertiary institutions & 71 & 23.4 \\
\hline No formal education & 21 & 6.9 \\
\hline Occupation distribution & Frequency & Percentage \\
\hline Formal sector & 113 & 37.3 \\
\hline Informal sector & 100 & 33 \\
\hline Unemployed & 90 & 29.7 \\
\hline Age Distribution & Frequency & Percentage \\
\hline Under 20 & 27 & 8.9 \\
\hline $20-29$ & 76 & 25.1 \\
\hline $30-39$ & 66 & 21.8 \\
\hline $40-49$ & 80 & 26.4 \\
\hline $50-59$ & 38 & 12.5 \\
\hline 60 and above & 16 & 5.3 \\
\hline Consumption of Sachet Water & Frequency & Percentage \\
\hline At home only & 40 & 13.2 \\
\hline In public only & 57 & 30.8 \\
\hline Both at home and in Public & 206 & Prequency \\
\hline Brand Loyalty & 211 & \\
\hline Specific brand & & \\
\hline No specific brand & 22 & \\
\hline & & \\
\hline
\end{tabular}

Appendix 3. Respondents Cross - checking Labeling Requirements $(n=303)$

\begin{tabular}{|l|c|c|}
\hline \multicolumn{1}{|c|}{$\begin{array}{c}\text { Cross - checking labeling } \\
\text { requirements }\end{array}$} & Checked & Did not check \\
\hline $\begin{array}{l}\text { Ghana Standard Board Mark Of } \\
\text { Conformity }\end{array}$ & 158 & 145 \\
\hline Address Of Manufacturer & 160 & 143 \\
\hline Expiry Date & 3 & 300 \\
\hline Mineral Content Specifications & 46 & 257 \\
\hline Manufacturing Date & 108 & 195 \\
\hline Sachet Batch Numbers & 0 & 303 \\
\hline
\end{tabular}




\section{Copyright Disclaimer}

2014, Vol. 2, No. 2

Copyright for this article is retained by the author(s), with first publication rights granted to the journal.

This is an open-access article distributed under the terms and conditions of the Creative Commons Attribution license (http://creativecommons.org/licenses/by/3.0/). 